\title{
Antioxidant Trace Elements and Oxidative Stress Levels Associated with Pasteurellosis in Camel-Calves (Camelus dromedarius)
}

\author{
Sherif Mohamed Shoieb ${ }^{1}$, Hussam Mohamed Mohamed Ibrahim², Mohamed Sayed-Ahmed ${ }^{2,3 *}$ and Sabry Ahmed El-khodery ${ }^{2}$ \\ ${ }^{1}$ Veterinary Teaching Hospital, Faculty of Veterinary Medicine, Mansoura University, Mansoura 35516, Egypt \\ ${ }^{2}$ Department of Internal Medicine and Infectious Diseases, Faculty of Veterinary Medicine, Mansoura University, Mansoura 35516, Egypt \\ ${ }^{3}$ Department of Clinical Pharmacy, College of Pharmacy, Jazan University, Jizan 45142, Saudi Arabia
}

\begin{abstract}
The aim of the present study was to evaluate changes in the electrolyte and trace elements profiles, antioxidants and oxidative stress level associated with pneumonic pasteurllosis in camel-calves in Saudi Arabia. For this purpose, venous blood samples were obtained from 48 camel-calves with pneumonic pasteurellosis and 48 randomly selected clinically healthy camel-calves (control group). Serum trace elements including sodium, potassium, chloride, copper and zinc were assayed. Serum malondialdehyde and low-density lipoprotein levels as well as total antioxidant capacity; hydrogen peroxide concentration; and activity of reduced glutathione, catalase, and superoxide dismutase were measured. Moreover, copper/zinc ratio and oxidative stress index were calculated. In camel-calves with pneumonic pasteurellosis, there was a significant $(P<0.05)$ decrease in the level of serum sodium, potassium, chloride, copper and zinc; total antioxidant capacity; and the activity of reduced glutathione, superoxide dismutase and catalase when compared with control group. Meanwhile, there was a significant $(P<0.05)$ increase in copper/ zinc ratio; level of malondialdehyde and low density lipoprotein; concentration of hydrogen peroxide; and oxidative stress index in pneumonic camel-calves compared to control group. The results indicate that electrolyte profiles trace element level and oxidants antioxidants balance are greatly disturbed in camel-calves with pasteurellosis.
\end{abstract}

Keywords: Respiratory diseases; Pasteurollosis; Antioxidants; Oxidants; Electrolytes; Trace elements; Camel-calves

\section{Introduction}

Nowadays, some interest and attention has been drawn toward camel because of its unique adaptive characteristics for survivability in harsh and difficult environment [1]. However, high mortality rate reported in camel-calves during the first three months of life is the major concern [2]. Respiratory airway diseases are encountered as an emerging health hazards to camel population worldwide due to significant mortalities and cost of treatment and vaccination [3]. The definite etiology of most respiratory tract diseases of camels has not yet been fully determined [4,5]. Moreover, several important predisposing factors as sudden climatic changes, poor management practices, exposure to various diseases, frequent travelling and poor nutrition may influence the occurrence of such diseases [2].

Pasteurellosis is a highly infectious, often fatal disease with very serious economic impact in feedlot animals [6,7]. It is the most common disease with wide prevalence and high mortality rate $[8,9]$. Septicaemic pasteurellosis affects mainly cattle, camels and to a lesser extent horse and sheep. Pasteurella multocida type B is the main cause, but type $\mathrm{D}$ and type $\mathrm{E}$ are occasionally isolated [6].

Several studies have reported that the imbalance between lipid peroxides and antioxidants in pneumonia may contribute to the damage of pulmonary endothelium [10]. Moreover, poor perfusion in pulmonary tissues may induce free radical processes and impairment of the antioxidant system with acceleration in the process of lipid peroxidation. The body is supported with a variety of antioxidants to overcome the toxic effects of these reactive oxygen species. Superoxide anions which are generated during metabolic processes are reduced to hydrogen peroxide in the presence of superoxide dismutase. Hydrogen peroxide was degraded in the presence of both catalase and glutathione peroxidase [11].
Oxidative stress is thought to play an important role in the pathogenesis of a number of lung diseases [12]. In respiratory tract infection, neutrophils are recruited to the pulmonary tissues to remove the invading micro-organisms by their phagocytic activity producing tissue damaging products such as reactive nitrogen species and nitric oxides modulating both acute and chronic inflammatory reactions [13]. When phagocytes are exposed to appropriate stimuli, they form large quantities of superoxide radical, an important precursor of other more reactive species that contribute to pulmonary damage [14].

Antioxidant trace elements produce consistent immune response and increase the resistance of calves against infection with Pasteurella hemolytica [15,16]. In calves with Mycoplasma bronchopneumonia, there was a significant alteration in major and trace elements in the bronchoalveolar lavage fluid [17]. In cattle, the oxidative stress level and antioxidant status have been described in bronchopneumonia caused by Mycoplasma bovis [18,19]. The camel, however, has been neglected for a long time and reports on pasteurellosis and their associated oxidant/antioxidant imbalance are scare. Therefore, the aim of the present study was to assess the alteration in electrolyte profile, trace element level and oxidative stress indices in camel-calves with pasteurellosis.

*Corresponding author: Mohamed Zakaria Sayed-Ahmed, Department of Interna Medicine and Infectious Diseases, Faculty of Veterinary Medicine, Mansoura University, Mansoura 35516, Egypt, Tel: +966594886878; Fax: +966173216837; E-mail: drzakaria-infect@hotmail.com

Received November 07, 2016; Accepted November 25, 2016; Published November 28, 2016

Citation: Shoieb SM, Ibrahim HMM, Sayed-Ahmed M, El-khodery SA (2016) Antioxidant Trace Elements and Oxidative Stress Levels Associated with Pasteurellosis in Camel-Calves (Camelus dromedarius). J Vet Sci Technol 7: 393. doi: 10.4172/2157-7579.1000393

Copyright: (C) 2016 Shoieb SM, et al. This is an open-access article distributed under the terms of the Creative Commons Attribution License, which permits unrestricted use, distribution, and reproduction in any medium, provided the 


\section{Materials and Methods}

\section{Animals}

A total of 96 camel-calves of both sexes at 3-11 months of age were studied. Of all, 48 camel-calves were exhibiting the clinical signs of pasteurellosis. In addition, other 48 apparently healthy camelcalves within the same age were randomly selected as a control group. The current study was carried out at three camel farms during 2013 in Shaqra, a town in central Saudi Arabia. The town is located near Ushaiger and about 190 kilometers north-west of the capital Riyadh. This study was approved by the Animal Welfare and Ethics Committee, Saudi Arabia, on December, 2012.

\section{Clinical examination}

Data concerned with the case history, clinical findings, and medical record for each camel-calf were recorded. A detailed clinical examination of camel-calves was carried out, and the clinical findings were recorded [6]. Camel-calves with pasteurellosis had clinical signs of anorexia, pyrexia $\left(40-41^{\circ} \mathrm{C}\right)$, dullness, lethargy, mucopurulent nasal and occular discharges, cough, hyperpnea, tachycardia, dyspnea and recumbency. Mandibular and cervical lymph nodes become enlarged and painful. In the terminal stage, the animal lied down and stretched its neck straight along the ground in an effort to inhale with dilated nostrils and opened mouth and die within 24-48 hours from the initial occurrence of the illness (Table 1).

\section{Blood samples}

Via jugular vein puncture, two venous blood samples $(10 \mathrm{~mL}$ each) were obtained from each camel-calf. The first blood sample was collected into anticoagulant containing tube (sodium ethylene diamine tetra-acetic acid, EMD Chemicals Inc., United States) for haematological examination. Meanwhile, the second blood sample was collected into a sterile tube without anticoagulant to obtain serum which was kept frozen at $-80^{\circ} \mathrm{C}$ for further biochemical analysis.

\section{Bacteriological isolation and identification}

Isolation and identification of Pasteurella multocida was carried out from blood and tissue samples obtained from live and dead camelcalves based on morphology, cultural characteristic and staining by Leishman's staining as previously described [20]. All isolates were identified as gram-negative, bipolar-staining short bacilli. Furthermore, the colonies suggestive of Pasteurella multocida were subjected to biochemical tests [21] for identification using of API 20E system (BioMe' rieux, Marcy-l'E' toile, France).

\section{Biochemical analysis}

Sodium, potassium, chloride, copper and zinc levels were determined by established procedures of atomic absorption spectrometry (Visible Absorption Spectrometer PD-303 UV, APEL, Japan). In addition, total antioxidant capacity, hydrogen peroxide concentration, and activity of reduced glutathione, catalase, and superoxide dismutase as well as level of malondialdehyde and low density lipoprotein were measured spectrophotometerically following standard methods using commercially available test kits (Biodiagnostic, Cairo, Egypt). As an indicator of the degree of oxidative stress, oxidative stress index (OSI) was calculated as the ratio of the total peroxide levels to the total antioxidant capacity. The OSI value was calculated as follows: $\times 100]$

\section{Statistical analysis}

Statistical analysis was carried out by using statistical software program (SPSS for Windows, version 16.0, SPSS Inc., Chicago, IL). Data were normally distributed; therefore, mean and standard deviation were statistically analyzed and presented. Paired-sample $T$-test was used to assess statistical differences between the groups. For all statistical examinations, results were considered significant at $\mathrm{P}<0.05$.

\section{Results and Discussion}

Hemorrhagic septicemia, one of fetal diseases of ruminant animals, is caused by Pasteurella multocida serotype B; a gramnegative bacterium secretes endotoxins in the blood stream, which are responsible for all manifestations of the disease [7,22]. These endotoxins trigger arachidonic acid metabolites resulting in the production of prostaglandins and leukotrienes causing moderate to severe pyrexia which is a hallmark of this disease [23].

Clinically, there was a significant increase in both respiratory and heart rates in camel-calves with pneumonic pasteurellosis. Moreover, wheezing with a high pitched breath sound was also detected during thoracic auscultation indicating severe lung injury (Table 1). Furthermore, four camel-calves $(8.3 \%)$ exhibited severe respiratory embaressment with deterioration of their health status and death occur within 24-48 hours from the initial occurrence of the illness. Such clinical findings were typical to the disease as described before in the previous reports [24-26]. Likewise, postmortem findings in camel-calves with pasteurellosis indicates septicemia. These findings were in agreement with those previously reported [7,27]. Depending on the recorded history, clinical findings, post mortem examination and results of bacteriological isolation and identification, these camelcalves were infected with Pasteurella multocida. The characters of the isolated colonies and their biochemical identification tests were in agreement with those previously reported [20]. However, in previous reports, several microorganisms including Pasteurella hemolytica were also recovered from lung of camels with pneumonic pasteurellosis [5], suggesting that other contributing factor may influence the severity of the disease.

Leukogram reflected a state of respiratory tract infection (Table 2), where leukocytosis could be an appropriate physiological response to an infectious or inflammatory process, which serves the sole job of killing bacterial infection. Similar findings were recorded in cattle [6], and horses with respiratory diseases [28]. Neutrophilia, lymphocytopenia and eosinophilia recorded in camel-calves with pasteurellosis indicates acute infection, and inflammation secondary to tissue injury, hypersensitivity reactions and stress. These findings were in agreement with those reported by Radostits et al. [6]. Meanwhile, the hematological findings in camel-calves with pasteurellosis revealed an increase of hemoglobin concentration, packed cell volume (PCV) \%, mean corpuscular volume (MCV) \% and mean corpuscular hemoglobin $(\mathrm{MCH}) \%$ when compared to control group (Table 3). Such changes in hematological parameters could be attributed to dehydration and hypovolemia which accompany the endotoxemia occurring in camelcalves with hemorrhagic septicemia [27].

Biochemically, sodium, potassium and chloride levels were significantly $(\mathrm{P}<0.05)$ decreased in camel-calves with pasteurellosis when compared with control group (Table 4 ). This could be attributed to dehydration and endotoxemia associating respiratory diseases with a resultant alteration in electrolyte profile associating such conditions $[6,29]$. Furthermore, there was a significant $(\mathrm{P}<0.05)$ decrease in 
Citation: Shoieb SM, Ibrahim HMM, Sayed-Ahmed M, El-khodery SA (2016) Antioxidant Trace Elements and Oxidative Stress Levels Associated with Pasteurellosis in Camel-Calves (Camelus dromedarius). J Vet Sci Technol 7: 393. doi: 10.4172/2157-7579.1000393

Page 3 of 5

Table 1: Clinical Findings in Camel-calves with Pneumonic Pasteurellosis.

\begin{tabular}{|c|c|c|c|c|c|c|c|}
\hline Groups & Temperature $\left({ }^{\circ} \mathrm{C}\right)$ & R.R. (Cycle/Min.) & H.R. (Beat/Min.) & Nasal discharge & Cough & Tracheal sound & Lung sound \\
\hline $\begin{array}{c}\text { Control } \\
(n=48)\end{array}$ & $37.4 \pm 0.19^{a}$ & $11.4 \pm 0.34^{a}$ & $51.9 \pm 2.7^{\mathrm{a}}$ & Absent (48/48) & Absent & Normal & Normal vesicular sound \\
\hline $\begin{array}{c}\text { Diseased } \\
(n=48)\end{array}$ & $39.3 \pm 0.17^{b}$ & $20.9 \pm 0.6^{b}$ & $78.0 \pm 1.68^{b}$ & $\begin{array}{c}\text { Mucoid }(23 / 48) \\
\text { Muco-purulent }(23 / 48) \\
\text { Absent }(2 / 48)\end{array}$ & $\begin{array}{l}\text { Dry cough }(8 / 48) \\
\text { Moist cough }(33 / 48) \\
\text { Absent }(7 / 48)\end{array}$ & $\begin{array}{c}\text { Tracheal rales } \\
(41 / 48)\end{array}$ & $\begin{array}{c}\text { Crackles }(9 / 48) \\
\text { Wheezes }(24 / 48) \\
\text { Exaggerated vesicular sound }(9 / 48) \\
\text { Mixed }(6 / 48)\end{array}$ \\
\hline
\end{tabular}

Abbreviation: R.R: Respiratory Rate; H.R: Heart Rate

a, $\mathbf{b}$ : Means with different superscript letters in the same column are significantly different at $\mathrm{P}<0.05$.

Table 2: Total and Differential Leukocytic Counts (mean values \pm SD) in Clinically Healthy Camel-calves and in Those with Pneumonic Pasteurellosis.

\begin{tabular}{|c|c|c|c|c|c|c|}
\hline Groups & TLC (count) $\times 10^{3}$ & Neutrophil \% & Lymphocyte \% & Monocyte \% & Eosinophil \% & Basophil \% \\
\hline $\begin{array}{l}\text { Control } \\
(n=48)\end{array}$ & $13.77 \pm 3.36^{a}$ & $39.03 \pm 4.63^{a}$ & $49.79 \pm 2.82^{a}$ & $4.69 \pm 1.66^{a}$ & $5.63 \pm 1.64 \mathrm{a}^{\mathrm{a}}$ & $0.37 \pm 0.21$ a \\
\hline $\begin{array}{c}\text { Diseased } \\
(n=48)\end{array}$ & $17.26 \pm 4.44^{b}$ & $71.42 \pm 10.44^{b}$ & $22.75 \pm 3.04^{b}$ & $3.25 \pm 2.12^{a}$ & $1.73 \pm 1.01^{b}$ & $0.65 \pm 0.93^{a}$ \\
\hline
\end{tabular}

Abbreviation: R.R: Respiratory Rate; H.R: Heart Rate

a, b: Means with different superscript letters in the same column are significantly different at $P<0.05$.

Table 3: Complete Blood Picture (mean values \pm SD) in Clinically Healthy Camel-calves and in Those with Pneumonic Pasteurellosis.

\begin{tabular}{|c|c|c|c|c|c|c|}
\hline Groups & RBCs (count) $\times 10^{6}$ & $\mathrm{Hb} \%$ & PCV \% & MCV \% & $\mathrm{MCH} \%$ & MCHC \% \\
\hline $\begin{array}{c}\text { Control } \\
(n=48)\end{array}$ & $13.70 \pm 0.79$ & $12.33 \pm 0.77^{a}$ & $23.45 \pm 2.51^{\mathrm{a}}$ & $19.32 \pm 5.83^{a}$ & $10.26 \pm 2.44^{a}$ & $38.96 \pm 5.67$ \\
\hline $\begin{array}{c}\text { Diseased } \\
(n=48)\end{array}$ & $16.98 \pm 1.75$ & $18.90 \pm 1.30^{b}$ & $35.43 \pm 3.51^{b}$ & $31.96 \pm 7.77^{b}$ & $23.61 \pm 9.63^{b}$ & $38.08 \pm 10.97$ \\
\hline
\end{tabular}

Abbreviations: RBCs: Red Blood Cells; Hb: Hemoglobin; PCV: Packed Cell Volume; MCV: Mean Corpuscular Volume; MCH: Mean Corpuscular Hemoglobin; MCHC: Mean Corpuscular Hemoglobin Concentration.

$\mathrm{a}, \mathrm{b}$ : Variables with different superscript in the same column are significantly different at $\mathrm{P}<0.05$.

Table 4: Electrolyte Profile and Trace elements status (mean values \pm SD) in Clinically Healthy Camel-calves and in Those with Pneumonic Pasteurellosis.

\begin{tabular}{|c|c|c|c|c|c|c|}
\hline Groups & Sodium $(\mu M / L)$ & Potassium $(\mu \mathrm{M} / \mathrm{L})$ & Chloride ( $\mu \mathrm{M} / L)$ & Copper ( $\mu \mathrm{M} / \mathrm{L})$ & Zinc $(\mu \mathrm{M} / L)$ & Copper/zinc ratio \\
\hline $\begin{array}{c}\text { Control } \\
(n=48)\end{array}$ & $160.07 \pm 13.2^{a}$ & $4.58 \pm 0.53^{a}$ & $65.67 \pm 6.23^{a}$ & $34.62 \pm 1.65^{a}$ & $42.81 \pm 2.15^{a}$ & $0.81 \pm 0.10^{\mathrm{a}}$ \\
\hline $\begin{array}{c}\text { Diseased } \\
\quad(n=48)\end{array}$ & $111.50 \pm 10.40^{b}$ & $2.30 \pm 1.22^{b}$ & $40.13 \pm 2.92^{b}$ & $24.60 \pm 1.85^{b}$ & $22.81 \pm 2.03^{b}$ & $1.08 \pm 0.61^{b}$ \\
\hline
\end{tabular}

a, b: Variables with different superscript in the same column are significantly different at $P<0.05$.

copper and zinc levels in camel-calves with pasteurellosis suggesting towards losses of these nutrients (Table 4). Indirect losses of these trace elements may be speculated during infectious diseases owing to accelerated metabolism or consumption, low intake due to inappetence or weakness, stress or pyrexia [30]. Moreover, copper/zinc ratio was significantly $(\mathrm{P}<0.05)$ increased in camel-calves with pasteurellosis compared with control group (Table 4). Serum zinc level was decreased more than copper. The significant changes of copper/zinc ratio with changes in the indices of oxidative stress suggest various degrees of airway inflammation. A similar finding of copper/zinc ratio has been recorded in horses with airway inflammation [28]. Furthermore, zinc and copper administration could modulate the humoral immune response to vaccines in cattle as recorded previously [31,32].

In pneumonic camel-calves, there was a significant $(\mathrm{P}<0.05)$ decrease in the total antioxidant capacity and activity of reduced glutathione, catalase, and superoxide dismutase when compared with control group (Table 5) indicating a worse state of oxidative stress. The antioxidant enzyme activities were decreased, and then the superoxide radical and hydrogen peroxide intermediate radicals accumulate. These oxygen free-radicals could undergo the Fenton's reaction, generating hydroxyl radicals, which may lead to lipid peroxidation in cells [33]. Therefore, the reason of increased lipid peroxidation in camel-calves with pasteurellosis may be related to decreased antioxidant enzymes activity. Furthermore, the decreased antioxidant enzymes activity, as found in the existing study, was attributed to its consumption in the protection of cells against oxidative injury by preventing the peroxidation process which is capable of inducing severe cellular damage [11]. In calves with bronchopneumonia, the reported decrease in the superoxide dismutase activity was correlated with high blood level of superoxide radicals as previously described [14]. Several studies have reported reduction of these antioxidant enzymes activities in horses with lower airway disease [28], and in human patients suffering pneumonia [34].

In the current investigation, there was a significant $(\mathrm{P}<0.05)$ increase in hydrogen peroxide concentration, levels of malondialdehyde and low density lipoprotein, and oxidative stress index in pneumonic camel-calves compared to their levels in healthy control group (Table 5). These findings were in agreement with those obtained in feedlot cattle with pneumonia caused by Mycoplasma bovis [19]. Hydrogen peroxide, which may be potentially dangerous for the lung, was produced normally by type II pneumocytes, endothelial cells and others [35-37]. In case of hypoxia, inflammation and insufficient antioxidant defense, hydrogen peroxide may initiate or intensify lung destruction. Furthermore, selenium deficiency with a resultant drastic decline in selenium dependent glutathione peroxidase activity produce a rise in cellular hydrogen peroxide concentration [28]. In a study conduced on buffaloes vaccinated against haemorrhagic septicaemia, polymorphonuclear cells generated significantly higher hydrogen 
Citation: Shoieb SM, Ibrahim HMM, Sayed-Ahmed M, El-khodery SA (2016) Antioxidant Trace Elements and Oxidative Stress Levels Associated with Pasteurellosis in Camel-Calves (Camelus dromedarius). J Vet Sci Technol 7: 393. doi: 10.4172/2157-7579.1000393

Page 4 of 5

Table 5: Antioxidants Level and Other Oxidative Stress Markers (mean values \pm SD) in Clinically Healthy Camel-calves and in Those with Pneumonic Pasteurellosis.

\begin{tabular}{|c|c|c|c|c|c|c|c|c|}
\hline Groups & TAC (mmol/L) & GSH (mg/dL) & SOD (U/mL) & MDA (nmol/mL) & $\mathrm{H}_{2} \mathrm{O}_{2}(\mu \mathrm{M} / \mathrm{L})$ & LDL (mmol/L) & CAT (U/L) & OSI \\
\hline $\begin{array}{c}\text { Control } \\
(n=48)\end{array}$ & $1.53 \pm 0.48^{a}$ & $8.19 \pm 0.53^{a}$ & $5.52 \pm 0.72^{a}$ & $11.26 \pm 1.75^{\mathrm{a}}$ & $10.2 \pm 4.5^{a}$ & $0.55 \pm 0.01^{\mathrm{a}}$ & $18.80 \pm 0.63^{a}$ & $0.74 \pm 0.36^{a}$ \\
\hline $\begin{array}{c}\text { Diseased } \\
\quad(n=48)\end{array}$ & $0.59 \pm 0.21^{\mathrm{b}}$ & $3.12 \pm 0.55^{b}$ & $2.55 \pm 0.23^{b}$ & $24.46 \pm 3.12^{\mathrm{b}}$ & $26.7 \pm 5.2^{b}$ & $2.28 \pm 0.65^{b}$ & $6.70 \pm 1.56^{b}$ & $4.18 \pm 1.49 b$ \\
\hline
\end{tabular}

Abbreviations: TAC: Total Antioxidant Capacity; GSH: Reduced Glutathione; SOD: Superoxide Dismutase; MDA: Malondialdehyde; $\mathrm{H}_{2} \mathrm{O}_{2}$ : Hydrogen Peroxide; LDL: Low Density Lipoprotein; CAT: Catalase; OSI: Oxidative Stress Index.

a, b: Variables with different superscript in the same column are significantly different at $P<0.05$

peroxide and nitric oxide, suggesting that these polymorphonuclear cells possessed a potent oxidant defense system even in the presence of Pasteurella multocida lipopolysaccharide, an antiphagocytic bacterium [38]. The results of the present study indicate that the antioxidant defense system is compromised in camel-calves with pneumonic pasteurellosis, which is evidenced by decreased total antioxidant capacity and increased malondialdehyde level, which may indirectly indicate increased whole free radical activity with a resultant increased oxidative stress index. Such findings coincide with those reported previously in draft horses with inflammatory airway disease [28].

\section{Conclusion}

All the results point to camel-calves with pneumonic pasteurellosis as a significant factor in alteration of the electrolyte and trace elements profiles and indices of oxidative stress. This is clearly demonstrated by low level of trace elements and electrolytes and high oxidative stress index in camel-calves with pasteurellosis compared with healthy ones. Furthermore, to the best of our knowledge, this is the first report on camel-calves with pasteurellosis. Further studies are needed to asssess the effect of trace elements and antioxidants supplementation on the clinical outcomes and oxidant antioxidant balance in camel-calves with pasteurellosis.

None of the authors of this paper has a financial or personal relationship with other people or organizations that could appropriately influence or bias the content of the paper.

\section{References}

1. Abdoun KA, Alsofi MA, Samara EM, Alhidary IA, Okab AB, et al. (2015) Evaluation of the effects of chromium supplementation on growth and nitrogen balance of camel calves under summer conditions. Trop Anim Health Prod 47: 619-621.

2. Kamber R, Farah Z, Rusch P, Hassig M (2001) Studies on the supply of immunoglobulin $\mathrm{G}$ to newborn camel-calves (Camelus dromedarius). J Dairy Res 68: 1-7.

3. Kebede F, Gelaye E (2010) Studies on major respiratory diseases of Camel (Camelus dromedarius) in Northeastern Ethiopia. Afr J Microbiol Res 4: 15601564.

4. Schwartz HJ (1992) Productive performance and productivity of dromedaries (Camelus dromedarius). Anim Res Dev 35: 86-98.

5. Wareth G, Murugaiyan J, Khater DF, Moustafa SA (2014) Subclinical pulmonary pathogenic infection in camels slaughtered in Cairo, Egypt. J Infect Dev Ctries 8: 909-913.

6. Radostits OM, Done SH (2007) Veterinary Medicine: A Textbook of the Diseases of Cattle, Sheep, Pigs, Goats, and Horses. Elsevier Saunders.

7. Hassan AKM, Mustafa AA (1985) Isolation of Pasteurella multocida type B from an outbreak of haemorrhagic septicaemia in camels in the Sudan. Rev Elev Med Vet Pays Trop 38: 31-33

8. Mohamed RA, Abdelsalam EB (2008) A review on pneumonic pasteurellosis (respiratory mannheimiosis) with emphasis on pathogenesis, virulence mechanisms and predisposing factors. BJVM 11: 139-160.

9. Al-Rawashdeh OF, Al-Ani FK, Sharrif LA, Al-Qudah KM, Al-Hami Y, et al. (2000)
A survey of camel (Camelus dromedarius) diseases in Jordan. J Zoo Wildl Med 31: 335-338.

10. Doelman CJA, Bast A (1990) Oxygen radicals in lung pathology. Free Radic Biol Med 9: 381-400.

11. Halliwell B (1994) Free radicals and antioxidants: a personal view. Nutr Rev 52: 253-265

12. MacNee W (2001) Oxidative stress and lung inflammation in airways disease. Eur J Pharmacol 429: 195-207.

13. Lykkesfeldt J, Svendsen O (2007) Oxidants and antioxidants in disease: oxidative stress in farm animals. Vet J 173: 502-511.

14. Ledwozyw A, Borowicz B (1991) The influence of normobaric hyperoxia on antioxidant enzymes activities and peroxidation product levels in rat lungs. Arch Vet Pol 32: 135-141.

15. Gengelbach GP, Ward JD, Spears JW, Brown TT (1997) Effects of coppe deficiency and copper deficiency coupled with high dietary iron or molybdenum on phagocytic cell function and response of calves to a respiratory disease challenge. J Anim Sci 75: 1112-1118.

16. Ward JD, Gengelbach GP, Spears JW (1997) The effects of copper deficiency with or without high dietary iron or molybdenum on immune function of cattle. $J$ Anim Sci 75: 1400-1408.

17. Suzuki K, Higuchi H, Iwano H, Lakritz J, Sera K, et al. (2012) Analysis of trace and major elements in bronchoalveolar lavage fluid of Mycoplasma bronchopneumonia in calves. Biol Trace Elem Res 145: 166-171.

18. Hermeyer K, Jacobsen B, Spergser J, Rosengarten R, Hewicker-Trautwein M (2011) Detection of Mycoplasma bovis by in-situ hybridization and expression of inducible nitric oxide synthase, nitrotyrosine and manganese superoxide dismutase in the lungs of experimentally-infected calves. J Comp Pathol 145: 240-250.

19. Schott C, Cai H, Parker L, Bateman KG, Caswell JL (2014) Hydrogen peroxide production and free radical-mediated cell stress in Mycoplasma bovis pneumonia. J Comp Pathol 150: 127-137.

20. Mochabo MO, Kitala PM, Gathura PB, Ogara WO, Eregae EM, et al. (2006) The socio-economic impact of important camel diseases as perceived by a pastoralist community in Kenya. Onderstepoort J Vet Res 73: 269-274.

21. DeRosa DC, Mechor GD, Staats JJ, Chengappa MM, Shryock TR (2000) Comparison of Pasteurella spp. simultaneously isolated from nasal and transtracheal swabs from cattle with clinical signs of bovine respiratory disease. J Clin Microbiol 38: 327-332.

22. Horadagoda NU, Hodgson JC, Moon GM, Wijewardana TG, Eckersall PD (2001) Role of endotoxin in the pathogenesis of haemorrhagic septicaemia in the buffalo. Microb Pathog 30: 171-178.

23. Raza MA, Muhammad G, Athar M, Khan MZ (2000) Comparative efficacy of three protocols for the treatment of haemorrhagic septicaemia in buffaloes and cattle. Pak Vet J 20: 35-39.

24. Angle N, Hoyt DB, Coimbra R, Liu F, Herdon-Remelius C, et al. (1998) Hypertonic saline resuscitation diminishes lung injury by suppressing neutrophil activation after hemorrhagic shock. Shock 9: 164-170.

25. Rizoli SB, Kapus A, Fan J, Li YH, Marshall JC, et al. (1998) Immunomodulatory effects of hypertonic resuscitation on the development of lung inflammation following hemorrhagic shock. J Immunol 161: 6288-6296.

26. Rizoli SB, Rhind SG, Shek PN, Inaba K, Filips D, et al. (2006) The immunomodulatory effects of hypertonic saline resuscitation in patients sustaining traumatic hemorrhagic shock: a randomized, controlled, doubleblinded trial. Ann Surg 243: 47-57.

27. Fraz MK (2011) Field epidemiology of an outbreak of hemorrhagic septicemia in 
Citation: Shoieb SM, Ibrahim HMM, Sayed-Ahmed M, El-khodery SA (2016) Antioxidant Trace Elements and Oxidative Stress Levels Associated with Pasteurellosis in Camel-Calves (Camelus dromedarius). J Vet Sci Technol 7: 393. doi: 10.4172/2157-7579.1000393

dromedary population of greater Cholistan Desert Pakistan. Pak Vet J 32: 31-34.

28. Youssef MA, El-Khodery SA, Ibrahim HMM (2012) Antioxidant trace elements in serum of draft horses with acute and chronic lower airway disease. Biol Trace Elem Res 150: 123-129.

29. Constable PD (1999) Hypertonic saline. Vet Clin North Am Food Anim Pract 15: 559-585.

30. Heidarpour M, Mohri M, Borji H, Moghdass E (2012) Oxidative stress and trace elements in camel (Camelus dromedarius) with liver cystic echinococcosis. Vet Parasitol 187: 459-463.

31. Salyer GB, Galyean ML, Defoor PJ, Nunnery GA, Parsons CH, et al. (2004) Effects of copper and zinc source on performance and humoral immune response of newly received, lightweight beef heifers. J Anim Sci 82: 2467-2473.

32. Nunnery GA, Vasconcelos JT, Parsons CH, Salyer GB, Defoor PJ, et al. (2007) Effects of source of supplemental zinc on performance and humoral immunity in beef heifers. J Anim Sci 85: 2304-2313.
33. Baskol G, Atmaca H, Tanrıverdi F, Baskol M, Kocer D et al. (2007) Oxidative stress and enzymatic antioxidant status in patients with hypothyroidism before and after treatment. Exp Clin Endocrinol Diabetes 115: 522-526.

34. Cui H, Yin SA, Gao H, Li G (1997) The comparison of selenium status between the children suffered from pneumonia and the normal children from kindergarten. Wei Sheng yan jiu = J Hyg Res 26: 242-244.

35. Art T, Kirschvink N, Smith N, Lekeux $P$ (1999) Indices of oxidative stress in blood and pulmonary epithelium lining fluid in horses suffering from recurrent airway obstruction. Equine Vet J 31: 397-401.

36. Deaton CM, Marlin DJ, Smith NC, Harris PA, Roberts CA, et al. (2004) Pulmonary epithelial lining fluid and plasma ascorbic acid concentrations in horses affected by recurrent airway obstruction. Am J Vet Res 65: 80-87.

37. Valko M, Leibfritz D, Moncol J, Cronin MT, Mazur M, et al. (2007) Free radicals and antioxidants in normal physiological functions and human disease. Int Biochem Cell Biol 39: 44-84.

38. Roy SC, More T, Pati US, Srivastava SK (1996) Effect of Pasteurella multocida vaccination on buffalo polymorphonuclear hydrogen peroxide and nitric oxide production. Vet Immunol Immunopathol 51: 173-178. 